\title{
Storage and Flux of Nutrients in Disturbed and Undisturbed Tropical Moist Forest of Eastern Nepal
}

\author{
Tilak Prasad Gautam $\mathbb{D}^{1}$ and Tej Narayan Mandal $^{2}$ \\ ${ }^{1}$ Mahendra Morang Adarsha Multiple Campus, Tribhuvan University, Biratnagar, Nepal \\ ${ }^{2}$ Post Graduate Campus, Tribhuvan University, Biratnagar, Nepal \\ Correspondence should be addressed to Tilak Prasad Gautam; tilakg673@gmail.com
}

Received 1 July 2018; Revised 1 September 2018; Accepted 1 October 2018; Published 18 October 2018

Academic Editor: Ignacio García-González

Copyright (c) 2018 Tilak Prasad Gautam and Tej Narayan Mandal. This is an open access article distributed under the Creative Commons Attribution License, which permits unrestricted use, distribution, and reproduction in any medium, provided the original work is properly cited.

\begin{abstract}
The disturbance activities in tropical forests shrink the nutrient cycling between the vegetation and soil. To understand the nutrient cycling in undisturbed and disturbed stands of mixed deciduous tropical forest of eastern Nepal, plant biomass was estimated within seventy randomly established sampling plots. The biomass values were multiplied with nutrient concentration of respective parts to estimate the nutrient stocks. The nutrient concentrations varied widely amongst components. In trees, concentrations of all nutrients were highest in leaves followed in decreasing order by fine roots $(<5 \mathrm{~mm})$ and twigs and then by branches, bole, and coarse roots. The contribution of different components to total nutrient stocks was in the following order: tree $>$ stand fine root $>$ shrub > herb, in both stands. The relative contribution of different components of trees to total nutrient stocks was in the following order: bole $>$ coarse root $>$ branch $>$ leaf $>$ twig $>$ fine roots. In trees, leaves and fine roots had greater gross uptake of nutrients than other components. The concentrations of different nutrients in the plants are in the following order: nitrogen > potassium $>$ phosphorus. Total nutrient return to the soil through the litterfall is almost 1.5 times greater than that from fine roots in both forests. In conclusion, various types of forest disturbances had adverse effect on the nutrient stocks and nutrient dynamics.
\end{abstract}

\section{Introduction}

Nutrient dynamics is an important phenomenon for the understanding of ecosystem functioning and ecological status. The nutrient cycling in forest ecosystem comprises cyclic circulation of nutrients between forest soils and plants. The nutrient status of a forest ecosystem depends on the balance between nutrient inputs (deposition, fixation, and weathering) and outputs (leaching and volatilization) [1]. In other words, nutrient uptake, their retention, and release are the three components of nutrient dynamics in forest ecosystem. More uptake of nutrients and less return to the soil leads to degradation of land and finally, lowering the productivity.

Litter and fine roots are regarded as the forest nutrient pool linking inputs, output, and turnover of nutrients. Nutrients accumulated in nonphotosynthetic parts (stem and roots) form the retention component while those accumulated in leaves return to the ecosystem through litter fall.
Litterfall is the main aboveground pathway for the return of organic matter and nutrients from plants to the soil [1]. Litter accumulation on the soil surface serves as temporary sink for nutrients which are liberated gradually by the process of decomposition, leaching, and mineralization. Further, fine roots also play a vital role in nutrient return to the ecosystem. Fine roots continuously add nutrients to the soil through their rapid turnover from belowground. Thus, litterfall and fine root decomposition maintain nutrient pools in the soil, influence primary production, and regulate energy flow and nutrient cycling in forest ecosystems.

In mature forests, nutrient uptake from the soil and nutrient loss through litter fall, canopy leaching, root exudation, and fine root death balance each other. Natural or anthropogenic disturbance can interrupt the tight nutrient cycle between soil and plant with the possible consequence of a reduction in tree growth or vitality [2]. Resource availability and disturbance are important factors that shape the composition, structure, and functioning of ecosystems 


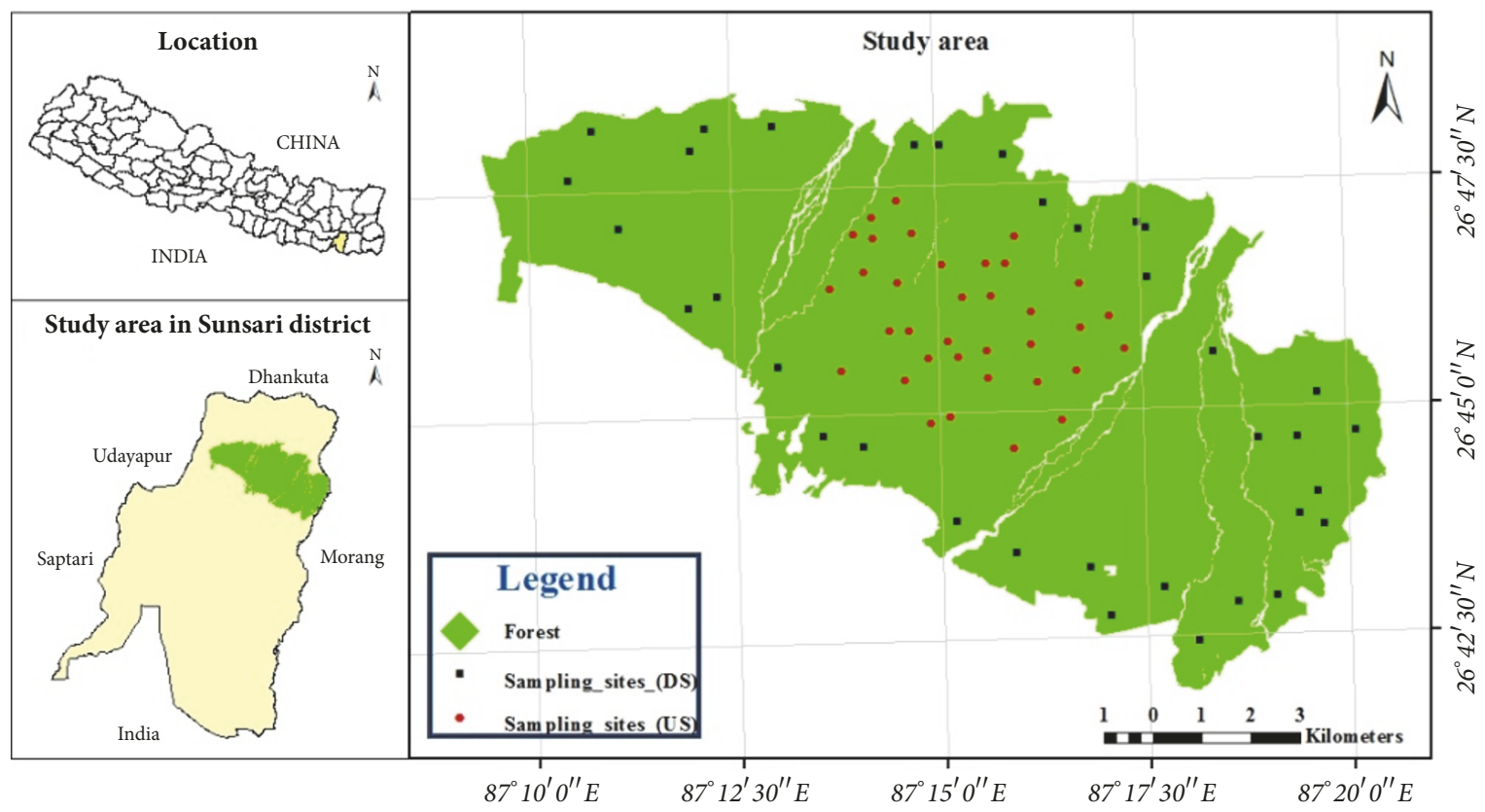

FIGURE 1: Map of the study area (tropical forest of Sunsari district, eastern Nepal).

[3]. Disturbances also destroy the nutrient conserving mechanisms of the undisturbed forest ecosystem and disrupt the soil-microbe-plant nutrient cycling [4]. As a consequence, nutrients tend to be lost from the system.

Tropical forests exhibit higher rates of primary production and the amounts of nutrients cycled than those in temperate forests [1]. Carbon sequestration capacity of tropical forests will also depend on available soil nutrients [5]. Nutrients like N, P, and K all limit forest plants growing on fertile soil in the lowland tropics [6]. However, despite the importance of tropical forests, the cycling of nutrients in these ecosystems is poorly understood $[1,7]$, particularly in the context of forest disturbance.

\section{Materials and Methods}

2.1. Study Area. Present study was conducted in a mixed deciduous lowland forest occupying an area of 11394 ha, located in the Sunsari district of Nepal (latitude $26^{\circ} 41^{\prime} \mathrm{N}$ to $26^{\circ} 48^{\prime} \mathrm{N}$ and longitude $87^{\circ} 09^{\prime} \mathrm{E}$ to $87^{\circ} 21^{\prime} \mathrm{E}$ ), within the altitude range of 220 to $370 \mathrm{~m}$, msl (Figure 1). The forest is bordered by dense settlement areas on the northern and southern sides while it is demarcated by a large river in the west and by a tributary in the east.

The climate is of tropical monsoon type with three distinct seasons: (i) dry and warm summer season (March to May); (ii) wet and warm rainy season (June to October); and (iii) dry and cool winter (November to February). Based on the data for the period of 2005 to 2014, mean monthly minimum air temperature ranged from $10.9^{\circ} \mathrm{C}$ to $25.3^{\circ} \mathrm{C}$ and maximum air temperature ranged from $22.6^{\circ} \mathrm{C}$ to $33.2^{\circ} \mathrm{C}$. The average annual rainfall is $1998.6 \mathrm{~mm}$, of which more than $79 \%$ is received during rainy season (Figure 2).
2.2. Status of the Forest. Present forest is a matured forest under the control of Government of Nepal. This climax forest is dominated by Shorea robusta. Other main associates in the forest are Haldina cordifolia, Lagerstroemia parviflora, Terminalia tomentosa, and Bombax ceiba. The core area of the forest is rich in species diversity, bears tallest trees reaching the height of 30 meters and largest trees having the girth of $659 \mathrm{~cm}$ at breast height. As the forest is bordered by dense settlements, several disturbance activities like livestock grazing, removal of timber, fuel-wood, litter, and lopping for fodder have caused forest degradation specially in the peripheral part. These activities stimulated the regeneration of plant species as well as the growth of invasive alien plants like Mikania micrantha, Lantana camara, and Chromolaena odorata. For the present study, the forest was divided into two parts: an undisturbed central part (core area) treated as undisturbed forest (UF) and peripheral part as disturbed forest (DF). Parameters used to classify the present forest as undisturbed and disturbed were as shown in Table 1.

2.3. Sample Collection and Chemical Analysis. At each forest, plant biomass was estimated within the thirty-five randomly established sampling plots. For the estimation of tree biomass ( $>10 \mathrm{~cm} \mathrm{GBH}$ ), quadrats of $20 \mathrm{~m} \times 20 \mathrm{~m}$ were used, while for the shrubs and herbs nested quadrats of $5 \mathrm{~m} \times 5 \mathrm{~m}$ and $1 \mathrm{~m} \times$ $1 \mathrm{~m}$ were used, respectively. Girths of all trees at breast height (1.37 $\mathrm{m}$ above the soil) and shrubs $(10 \mathrm{~cm}$ above the ground level) lying within each plot were measured. Biomass of trees in plots was estimated by using girth: biomass allometric equations for submontane Sal forest in Southern Siwaliks [10]. For estimating coarse root biomass, roots: shoot ratio of 0.21 proposed for lowland tropical forests was used [11]. 
TABLE 1: Parameters used to classify the studied forest as undisturbed and disturbed.

\begin{tabular}{lcc}
\hline Parameters & Undisturbed forest & Disturbed forest \\
\hline Canopy area $\left(\mathrm{m}^{2} /\right.$ tree $)$ & $154-227$ & $28-78$ \\
Crown cover $(\%)$ & $70-80$ & $30-40$ \\
Tree density $\left(\right.$ indi. $\left.^{-1} \mathrm{ha}^{-1}\right)$ & 466 & 234 \\
Tree stumps $\left(\mathrm{ha}^{-1}\right)$ & Absent & 70 \\
\hline
\end{tabular}

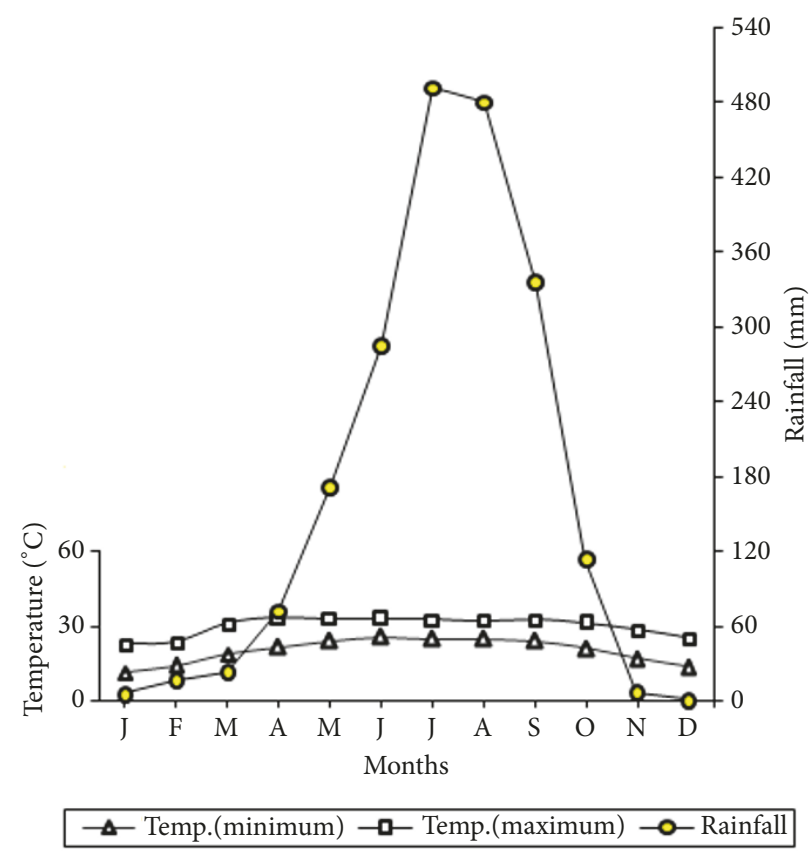

Figure 2: Ombrothermic representation of the climate of moist tropical forest region of Sunsari district, eastern Nepal. The data pertain to the period 2005-2014 (source: Department of Meteorology, Nepal).

Samples of different tree components (bole, branch, and twig) were collected from each sampling plots from the representative individuals of all available girth classes. Samples of shrubs from different components and herbs (aboveground) were collected from each site. Composite samples of all components of trees, shrubs, and herbs were oven dried at $80^{\circ} \mathrm{C}$ to constant weight.

Litterfall samples (leaf litter and nonleaf litter) which were collected from one litter trap at each quadrat (established to determine plant biomass) at monthly intervals were pooled together in proportion to their volume to represent annual samples for each site. The oven dried samples of each component of plant, leaf litter, and wood litter ground separately and passed through $1 \mathrm{~mm}$ mesh screen. Three separate samples of various components were analyzed for each site. The fine roots (divided into $<2$ and $2-5 \mathrm{~mm}$ diameter) collected from 0-30 cm depth from all quadrats were mixed separately according to their size class, oven dried at $80^{\circ} \mathrm{C}$ to constant weight, and ground for chemical analysis.

The total nitrogen $(\mathrm{N})$ concentration was determined by micro-Kjeldahl method [12]. Phosphorus (P) was determined colorimetrically, and potassium $(\mathrm{K})$ and calcium $(\mathrm{Ca})$ by atomic absorption spectrophotometer [13]. Calcium was determined only in fresh green leaf and leaf litter samples.
Soil samples were collected from 35 randomly selected sampling plots each in UF and DF as designed for vegetation analysis, during summer season. At each plot, the soil was collected from three pits $\left(10 \times 10 \times 30 \mathrm{~cm}^{3}\right.$ each, divided into two depths: upper, $0-15$ and lower, $15-30 \mathrm{~cm}$ ). For each depth, the soils of three pits were mixed and pooled as one replicate. Air dried soil samples were sieved through a $2 \mathrm{~mm}$ mesh screen and used for further analysis. Total nitrogen $(\mathrm{N})$ was determined by micro-Kjeldhal method and total phosphorus (P) by ammonium molybdate-stannous chloride blue color method [14]. Potassium was estimated by atomic absorption spectrophotometer.

2.4. Computation Procedure. The nutrient stocks in plant components were calculated by multiplying their dry weights with respective mean nutrient concentrations. The stocks in different components were summed to obtain total nutrient storage in the vegetation. The gross uptake of nutrients was calculated by multiplying the values of net production of different components with their respective nutrient concentrations. The nutrient uptakes by trees, shrubs, herbs, and fine roots were summed to estimate the gross uptake by the vegetation [15]. 
TABLE 2: Nutrient concentrations (\%) (mean \pm SE) in tree, shrub, herb, and fine root of moist tropical forest in Sunsari district, eastern Nepal.

\begin{tabular}{|c|c|c|c|}
\hline Components & $\mathrm{N}$ & $\mathrm{P}$ & $\mathrm{K}$ \\
\hline \multicolumn{4}{|l|}{ Trees } \\
\hline Bole & $0.57 \pm 0.04$ & $0.05 \pm 003$ & $0.57 \pm 0.03$ \\
\hline Branch & $0.62 \pm 0.06$ & $0.06 \pm 0.007$ & $0.58 \pm 0.03$ \\
\hline Twig & $0.69 \pm 0.06$ & $0.08 \pm 0.005$ & $0.57 \pm 0.04$ \\
\hline Leaf & $1.73 \pm 0.18$ & $0.2 \pm 0.02$ & $1.12 \pm 0.11$ \\
\hline Coarse root & $0.49 \pm .03$ & $0.05 \pm 0.002$ & $0.32 \pm 0.02$ \\
\hline \multicolumn{4}{|l|}{ Shrubs } \\
\hline Stem & $0.78 \pm 0.07$ & $0.07 \pm 0.004$ & $1.21 \pm 0.12$ \\
\hline Leaf & $2.49 \pm 0.31$ & $0.19 \pm 0.001$ & $1.56 \pm 0.20$ \\
\hline Coarse root & $0.67 \pm 0.04$ & $0.04 \pm 0.004$ & $0.49 \pm 0.03$ \\
\hline Herbs aboveground & $1.47 \pm 0.11$ & $0.18 \pm 0.015$ & $1.42 \pm 0.17$ \\
\hline \multicolumn{4}{|l|}{ Stand fine roots } \\
\hline $0-2 \mathrm{~mm}$ & $0.9 \pm 0.05$ & $0.07 \pm 0.003$ & $0.71 \pm 0.05$ \\
\hline $2-5 \mathrm{~mm}$ & $0.63 \pm 0.03$ & $0.05 \pm 0.002$ & $0.69 \pm 0.04$ \\
\hline
\end{tabular}

The turnover time, as an index of nutrient cycling rate for different nutrients, was computed as the ratio of stock/annual gross uptake [16]. The nutrient retranslocation in the leaves during senescence was estimated by using nutrient: Ca ratios, assuming that $\mathrm{Ca}$ is immobile [1]:

$$
\% \text { re-translocation }=\frac{x-y}{x} \times 100
$$

where $\mathrm{x}=$ (nutrient concentration in green leaf) / $(\mathrm{Ca}$ concentration in green leaf) and $\mathrm{y}=$ (nutrient concentration in leaf litter) / (Ca concentration in leaf litter)

The net uptake of nutrients by trees, shrubs, and herbs was computed by subtracting the amount retranslocated from the gross uptake. The amounts of nutrients transferred to the forest floor were computed by multiplying the annual litterfall weight and nutrient concentration data. The nutrient-use efficiency was calculated by using under mentioned formula [17]:

$$
\text { Nutrient use efficiency }=\frac{\text { Net primary production }}{\text { Net nutrient uptake }}
$$

The turnover rate $(k)$ for each element on the forest floor was calculated as $k=A /(A+F)[18]$, where $A$ is the amount of nutrient added to the forest floor annually by litterfall and $F$ is the nutrient content of the lowest value of standing crop of litter in the annual cycle. Turnover time $(t)$ is the reciprocal of the turnover rate $(k)$ and is expressed as $t=1 / k$.

Nutrients (N, P, and $\mathrm{K})$ content in soil was calculated using the formula: Nutrient stock in soil = Concentration of nutrient $\times$ Soil depth $\times$ Bulk density.

\section{Results}

3.1. Nutrient Concentration. Nutrient concentrations in different components of trees, shrubs, herbs, and fine roots are summarized in Table 2. The relative concentrations of different nutrients, in decreasing order, were nitrogen $(\mathrm{N})>$ potassium $(\mathrm{K})>$ phosphorus $(\mathrm{P})$ in herbs, shrubs, and trees, indicating that the plants are richer in $\mathrm{N}$ than $\mathrm{K}$. The nutrient concentrations varied widely amongst components. In trees, concentrations of all nutrients were highest in leaves followed in decreasing order by fine roots $(<5 \mathrm{~mm})$ and twigs and then by branches, bole, and coarse roots.

$\mathrm{N}$ : $\mathrm{P}$ ratio in tree and tree leaves were 9.3 and 8.7, respectively. N: P ratio in shrubs was maximum (13.1), while in herbs it was minimum (8.2). Fine roots, the active absorptive parts for nutrient uptake from the soil, had higher concentration of nutrients and $\mathrm{N}$ : $\mathrm{P}$ ratio than coarse roots (Table 2). In fine roots, concentration of nutrients was in the order $\mathrm{N}>\mathrm{K}>\mathrm{P}$. Nutrient concentration in fine roots decreased with increase in root diameter. Fine roots of $<2 \mathrm{~mm}$ size ranked next to tree leaves with respect to the concentrations of $\mathrm{N}$ and $\mathrm{K}$. It is evident that the short lived and rapidly cycling components of tree (leaf and fine root) accumulated high concentrations of nutrients than the relatively permanent parts (bole).

3.2. Nutrient Stocks in Vegetation. The nutrient stocks in different components of plants differed considerably in undisturbed forest (UF) and disturbed forest (DF) (Table 3). The differences in nutrient stocks were accounted by the variations in biomass and not due to concentration. The vegetation of UF contained more than double $\mathrm{N}, \mathrm{P}$, and $\mathrm{K}$ stocks than DF.

The contribution of different components to total nutrient stocks was in the following order: tree > stand fine root > shrub $>$ herb, in both forests. In shrubs, relative contribution of different components to total nutrient stocks was in the following order: leaf $>$ stem $>$ coarse root; however in trees the trends were as follows: bole $>$ coarse root $>$ branch $>$ leaf $>$ twig $>$ fine roots for all estimated nutrients. In trees, boles and coarse roots had lower nutrient concentrations but greater nutrient stocks than other components. Therefore, the maximum loss of all nutrients occurs through stem harvest. Aboveground nutrient stocks comprised $84-89 \%$ of the total vegetation stocks in both forests while rest is allocated to underground parts. Fine root of smaller size class $(0-2 \mathrm{~mm}$ 
TABLE 3: Nutrient stocks $\left(\mathrm{kg} \mathrm{ha}^{-1}\right)$ in tree, shrub, herb, and fine root in undisturbed and disturbed forest stands of moist tropical forest of Sunsari district, eastern Nepal (mean \pm SE).

\begin{tabular}{|c|c|c|c|c|c|c|}
\hline \multirow{2}{*}{ Components } & \multicolumn{3}{|c|}{ Undisturbed forest } & \multicolumn{3}{|c|}{ Disturbed forest } \\
\hline & $\mathrm{N}$ & $\mathrm{P}$ & $\mathrm{K}$ & $\mathrm{N}$ & $\mathrm{P}$ & $\mathrm{K}$ \\
\hline Trees & $5612.5 \pm 481$ & $527.0 \pm 54$ & $5118.7 \pm 49$ & $2594.0 \pm 144$ & $243.5 \pm 22$ & $2366.6 \pm 251$ \\
\hline Bole (\%) & 62 & 58 & 68 & 62 & 58 & 68 \\
\hline Branch (\%) & 13 & 13 & 13 & 14 & 14 & 14 \\
\hline Twig (\%) & 4 & 5 & 4 & 4 & 5 & 3 \\
\hline Leaf (\%) & 7 & 8 & 5 & 6 & 8 & 5 \\
\hline C. $\operatorname{root}(\%)$ & 14 & 16 & 10 & 14 & 16 & 10 \\
\hline Shrubs & $49.9 \pm 2.7$ & $3.9 \pm 0.3$ & $46.7 \pm 0.7$ & $64.7 \pm 4.3$ & $5.0 \pm 0.3$ & $63.5 \pm 4.7$ \\
\hline Stem $(\%)$ & 31 & 36 & 52 & 36 & 42 & 57 \\
\hline Leaf (\%) & 50 & 49 & 33 & 44 & 44 & 28 \\
\hline Root (\%) & 19 & 15 & 15 & 20 & 16 & 15 \\
\hline Herbs & $20.6 \pm 1.2$ & $2.5 \pm 0.2$ & $19.9 \pm 1.0$ & $17.6 \pm 1.0$ & $2.2 \pm 0.1$ & $17.0 \pm 1.1$ \\
\hline Stand fine root & $55.2 \pm 3.1$ & $4.3 \pm 0.3$ & $46.8 \pm 2.6$ & $28.1 \pm 1.8$ & $2.2 \pm 0.1$ & $23.7 \pm 2.2$ \\
\hline $0-2 \mathrm{~mm}(\%)$ & 81 & 81 & 75 & 82 & 82 & 76 \\
\hline $2-5 \mathrm{~mm}(\%)$ & 19 & 19 & 25 & 18 & 18 & 24 \\
\hline Total Vegetation & $5738.2 \pm 497$ & $537.7 \pm 41$ & $5232.1 \pm 402$ & $2704.4 \pm 156$ & $252.9 \pm 16$ & $2470.8 \pm 187$ \\
\hline
\end{tabular}

TABLE 4: Gross uptake of nutrients $\left(\mathrm{kg} \mathrm{ha}^{-1} \mathrm{y}^{-1}\right)$ in tree, shrub, herb, and fine root in undisturbed and disturbed forest stands of moist tropical forest of Sunsari district, eastern Nepal (mean \pm SE).

\begin{tabular}{|c|c|c|c|c|c|c|}
\hline \multirow{2}{*}{ Components } & \multicolumn{3}{|c|}{ Undisturbed forest } & \multicolumn{3}{|c|}{ Disturbed forest } \\
\hline & $\mathrm{N}$ & $\mathrm{P}$ & $\mathrm{K}$ & $\mathrm{N}$ & $\mathrm{P}$ & $\mathrm{K}$ \\
\hline Trees & $208.8 \pm 15$ & $23.2 \pm 1.3$ & $151.3 \pm 8.2$ & $106.8 \pm 7.5$ & $11.8 \pm 0.5$ & $77.9 \pm 2.8$ \\
\hline Bole (\%) & 13 & 10 & 18 & 16 & 13 & 22 \\
\hline Branch (\%) & 3 & 2 & 3 & 3 & 3 & 4 \\
\hline Twig (\%) & 13 & 14 & 15 & 9 & 10 & 11 \\
\hline Leaf $(\%)$ & 68 & 71 & 61 & 68 & 71 & 60 \\
\hline Coarse root (\%) & 3 & 3 & 3 & 4 & 3 & 3 \\
\hline Shrubs & $5.3 \pm 0.3$ & $0.4 \pm 0.02$ & $5.6 \pm 0.3$ & $6.9 \pm 0.4$ & $0.5 \pm 0.02$ & $7.6 \pm 0.5$ \\
\hline Stem $(\%)$ & 44 & 50 & 64 & 46 & 60 & 67 \\
\hline Leaf (\%) & 33 & 25 & 20 & 29 & 40 & 16 \\
\hline Root (\%) & 23 & 25 & 16 & 25 & 20 & 16 \\
\hline Herbs & $25.0 \pm 1.7$ & $3.1 \pm 0.1$ & $24.1 \pm 1.8$ & $19.1 \pm 1.0$ & $2.3 \pm 0.01$ & $18.5 \pm 1.3$ \\
\hline Stand fine root & $43.3 \pm 2.6$ & $3.4 \pm 0.1$ & $36.7 \pm 1.8$ & $24.0 \pm 1.2$ & $1.9 \pm 0.01$ & $20.2 \pm 0.8$ \\
\hline $0-2 \mathrm{~mm}(\%)$ & 81 & 79 & 75 & 83 & 79 & 78 \\
\hline $2-5 \mathrm{~mm}(\%)$ & 19 & 21 & 25 & 17 & 21 & 22 \\
\hline Total vegetation & $282.4 \pm 18$ & $30.1 \pm 1.7$ & $217.7 \pm 13.4$ & $156.8 \pm 8.2$ & $16.5 \pm 1.0$ & $124.2 \pm 9.5$ \\
\hline
\end{tabular}

diameter) contained quite greater nutrient stocks than that of larger size class (2-5 mm diameter) (Table 3).

3.3. Nutrient Uptake and Retranslocation. The gross uptake of nutrients (total amount of nutrients associated with net production) in different components of vegetation in both forest stands is presented in Table 4. As expected, UF showed higher gross uptake as compared to DF. In UF the ranges of gross uptake of nutrients in vegetation $\left(\mathrm{kg} \mathrm{ha}^{-1} \mathrm{yr}^{-1}\right)$ were 282.4 N, 30.1 P, and 217.7 K, whereas in DF they were $156.8 \mathrm{~N}$, 16.5 P, and $124.2 \mathrm{~K}$. The gross uptake of nutrients was in the order of tree $>$ herb $>$ shrub. In trees, leaves and fine roots had lower biomass but greater gross uptake of nutrients than other components.

A marked retranslocation of $\mathrm{N}, \mathrm{P}$, and $\mathrm{K}$ was recorded in senescing leaves in different growth forms (Table 5). Retranslocation of $\mathrm{N}$ and $\mathrm{K}$ was lesser in herbaceous species than shrub and tree species, whereas retranslocation of $\mathrm{P}$ was minimum in shrubs. Retranslocation behaviour in trees showed an order of $\mathrm{P}>\mathrm{N}>\mathrm{K}$. The net uptake of nutrients (actual amount of nutrients transferred from soil to plant after correction for retranslocation) is given in Table 6. Distinctly higher net uptake of nutrients was recorded in UF than DF.

Trees shared $68-70 \%$ of total net uptake of different nutrients in UF, whereas the range of total net uptake in 
TABle 5: Percentage nutrient retranslocation during leaf senescence in moist tropical forest of Sunsari district, eastern Nepal.

\begin{tabular}{lccc}
\hline Components & \multicolumn{3}{c}{ Nutrients } \\
& $\mathrm{N}$ & $\mathrm{P}$ & $\mathrm{K}$ \\
\hline Herbs & 36 & 53 & 35 \\
Shrubs & 49 & 44 & 52 \\
Trees & 48 & 59 & 41 \\
\hline
\end{tabular}

DF was $58-64 \%$. Moreover, the share of shrubs and herbs (aboveground parts) to total net uptake ranged between 2-7\% in UF and $9-15 \%$ in DF. The share of trees in total net uptake decreased in DF, whereas that of shrubs and herbs decreased in UF. Fine roots accounted for substantial fractions of total net uptake for all nutrients (18-22\%) in both stands. The sequential arrangement of net nutrient uptake was $\mathrm{N}>\mathrm{K}>$ $\mathrm{P}$ in both stands. The relative contributions of different tree components to total net nutrient uptake were in the following order: Leaf $>$ Fine root $>$ Twig $>$ Bole $>$ Coarse root/Branch.

3.4. Nutrient Return through Litterfall. The concentrations of all nutrients in leaf litter were higher than in nonleaf litter in both stands (Table 7). The total input of nutrients $\left(\mathrm{kg} \mathrm{ha}^{-1}\right.$ $\mathrm{yr}^{-1}$ ) to the soil through litterfall in UF was more than double as compared to DF (Table 8). Of the total annual nutrient input through litterfall, leaf litter accounted for $78-87 \%$ in UF and $85-90 \%$ in DF.

3.5. Nutrient-Use Efficiency. Generally, the nutrient-use efficiencies were greater in trees followed by shrubs and herbs (Table 9). Difference with respect to N, P, and K-use efficiencies were distinct amongst different growth forms. In trees, nutrient-use efficiencies increased in DF while in shrubs only the $\mathrm{N}$ and $\mathrm{P}$-use efficiencies were increased in DF.

3.6. Turnover of Nutrients in Standing Vegetation. Turnover time for nutrients in vegetation showed variations due to growth form as well as with the forest disturbance (Table 10). Trees showed greater turnover time followed in decreasing order by shrubs and herbs in both forest stands. For the stand vegetation as a whole, the turnover time in both forests was maximum for K (19.9-24.0 years) followed by $\mathrm{N}$ (17.2-20.3) and minimum for $\mathrm{P}$ (15.3-17.9).

3.7. Nutrients in Litter Mass and Turnover of Nutrients on Forest Floor. Litter on the forest floor (litter mass) varies seasonally with litterfall. Standing state of nutrients in litter mass decreased with forest disturbance. The nutrient stocks in litter mass were in the following order: $\mathrm{N}>\mathrm{K}>\mathrm{P}$ in both forests (Table 11). Of the total nutrients in litter mass, 63-65\% nutrients were present in fresh litter and rest in partly decayed litter.

The turnover rate and turnover time for different litter nutrients on the forest floor are given in Table 12. The turnover rates were slightly higher in the UF and lower in the DF. In contrary, turnover time for all nutrients was relatively higher in DF.
3.8. Nutrient Budget and Flux. Nutrient budget for different nutrients in vegetation is presented in Table 13. The nutrient stocks in vegetation decreased from undisturbed to disturbed forest. Substantial quantities of nutrients were retranslocated during leaf senescence in both forest stands. Further, the retranslocated amount was almost double in UF as compared to DF.

Nutrient return to the soil through litterfall exceeded over the return through fine roots. Litterfall returned about 1.5 times greater the amount of $\mathrm{N}, \mathrm{P}$, and $\mathrm{K}$ than fine roots in both stands. Further, total return of N, P, and $\mathrm{K}$ through both litterfall and fine roots was more than double in UF as compared to DF. In UF percentage values of total return with respect to net uptake were relatively higher than DF (Table 13). Conversely, percentage retention of net uptake of $\mathrm{N}, \mathrm{P}$, and $\mathrm{K}$ was less in UF in comparison to DF. The higher value of nutrient retention in DF indicates the nutrient aggregation whereas lower retention in UF implies that most of the nutrients are recycled.

3.9. Nutrient Dynamics in the Context of Disturbance. Nutrient cycling in UF and DF has been modeled in Figures 3 and 4. Average stand stocks of nutrients are given in compartments and the net annual fluxes between compartments are represented as arrows. The amount of nutrients present in the soil to a depth of $30 \mathrm{~cm}$ is considered as source. In these flow diagrams, $\mathrm{N}$ and $\mathrm{P}$ are better accounted for, because their total contents in the soil are estimated. In soil, the content determined for a cation $(\mathrm{K})$ comprises its exchangeable state only. The direction of nutrient flux from soil to foliage indicates a one-way movement, although it is understood that the nutrients utilized by the foliage in organic matter synthesis are redistributed amongst different components during the assimilate transfers.

Aboveground nutrient stocks comprised $84-89 \%$ of the total vegetation stocks in both forests. In UF, of the total nutrients stored in the ecosystem (plant + litter + soil to a depth of $30 \mathrm{~cm}$ ), 17-44\% of the total $\mathrm{N}$ and $\mathrm{P}$ were stored in the vegetation, $55-81 \%$ in soil, and only a negligible fraction $(0.2-0.4 \%)$ in litter mass, whereas in DF, the vegetation comprised 9-37\%, soil accounted for $63-91 \%$ and litter mass accounted for $0.1-0.4 \%$ of nutrient storage.

\section{Discussion}

Forest disturbances resulted in the formation of fragmented, exposed, and nutrient poor sites thereby increasing the herb and shrub species diversities. The open canopy in the DF facilitated direct heating of soil and finally lowering soil moisture. The litter removal also lowered the organic matter inputs to the soil. All these factors favoured the growth and dominancy of alien exotic species like Chromolaena odorata and Lantana camara. The tree felling for timber, firewood collection, lopping, and grazing in the DF resulted in poor biomass and net primary production [19] and finally the nutrient stocks.

In the UF, the dense canopy of trees tended to suppress the undergrowth from obtaining sufficient sunlight required 
TABLE 6: Net uptake of nutrients $\left(\mathrm{kg} \mathrm{ha}^{-1} \mathrm{y}^{-1}\right)$ after adjustment for re-translocation in tree, shrub, herb, and fine root in undisturbed and disturbed forest stands of moist tropical forest of Sunsari district, eastern Nepal (mean \pm SE).

\begin{tabular}{|c|c|c|c|c|c|c|}
\hline \multirow{2}{*}{ Components } & \multicolumn{3}{|c|}{ Undisturbed forest } & \multicolumn{3}{|c|}{ Disturbed forest } \\
\hline & $\mathrm{N}$ & $\mathrm{P}$ & $\mathrm{K}$ & $\mathrm{N}$ & $\mathrm{P}$ & $\mathrm{K}$ \\
\hline Trees & $140.4 \pm 13.9$ & $13.5 \pm 0.8$ & $113.5 \pm 4.8$ & $72.0 \pm 2.2$ & $6.8 \pm 0.3$ & $58.7 \pm 2.9$ \\
\hline Shrubs & $4.5 \pm 0.2$ & $0.36 \pm 0.01$ & $5.0 \pm 0.3$ & $5.9 \pm 0.4$ & $0.4 \pm 0.02$ & $7.0 \pm 0.4$ \\
\hline Herbs & $19.5 \pm 1.3$ & $2.1 \pm 0.1$ & $19.0 \pm 1.3$ & $14.9 \pm 0.9$ & $1.6 \pm 0.1$ & $14.6 \pm 1.0$ \\
\hline Stand fine root & $43.3 \pm 2.6$ & $3.4 \pm 0.1$ & $36.7 \pm 1.8$ & $24.0 \pm 1.2$ & $1.9 \pm 0.01$ & $20.2 \pm 0.8$ \\
\hline Total vegetation & $207.7 \pm 17$ & $19.4 \pm 1.2$ & $164.2 \pm 9.4$ & $116.8 \pm 6.2$ & $10.7 \pm 0.7$ & $100.5 \pm 6.8$ \\
\hline
\end{tabular}

TABLE 7: Concentration of nutrients (\%) (mean \pm SE) in litter of moist tropical forest in Sunsari district, eastern Nepal.

\begin{tabular}{lcccc}
\hline Components & $\mathrm{N}$ & $\mathrm{P}$ & $\mathrm{K}$ & $\mathrm{Ca}$ \\
\hline Leaf litter & & & $0.62 \pm 0.04$ & \\
Trees & $0.85 \pm 0.05$ & $0.08 \pm 0.003$ & $0.65 \pm 0.05$ & $0.8 \pm 0.05$ \\
Shrubs & $1.1 \pm 0.09$ & $0.09 \pm 0.007$ & $0.69 \pm 0.06$ & \\
Herbs & $0.81 \pm 0.04$ & $0.07 \pm 0.006$ & & \\
Mean & $0.92 \pm 0.05$ & $0.08 \pm 0.005$ & & $0.22 \pm 0.01$ \\
Non leaf litter & & & $0.24 \pm 0.02$ \\
Trees & $0.66 \pm 0.05$ & $0.05 \pm 0.003$ & $0.03 \pm 0.06$ \\
Shrubs & $0.7 \pm 0.07$ & $0.05 \pm 0.003$ & 0.01 \\
Mean & $0.68 \pm 0.05$ & $0.05 \pm 0.004$ & \\
\hline
\end{tabular}

TABLE 8: Amount of nutrients $\left(\mathrm{kg} \mathrm{ha}^{-1} \mathrm{yr}^{-1}\right)$ in litterfall in undisturbed and disturbed forest stands of moist tropical forest of Sunsari district, eastern Nepal (mean $\pm \mathrm{SE}$ ).

\begin{tabular}{|c|c|c|c|c|c|c|}
\hline \multirow{2}{*}{ Components } & \multicolumn{3}{|c|}{ Undisturbed forest } & \multicolumn{3}{|c|}{ Disturbed forest } \\
\hline & $\mathrm{N}$ & $\mathrm{P}$ & $\mathrm{K}$ & $\mathrm{N}$ & $\mathrm{P}$ & $\mathrm{K}$ \\
\hline Leaf & $74.5 \pm 6.5$ & $6.5 \pm 0.4$ & $55.9 \pm 5.6$ & $37.7 \pm 2.8$ & $3.3 \pm 0.1$ & $28.3 \pm 2.4$ \\
\hline Non leaf & $25.2 \pm 1.6$ & $1.9 \pm 0.1$ & $8.5 \pm 0.7$ & $8.8 \pm 0.5$ & $0.7 \pm 0.05$ & $3.0 \pm 0.02$ \\
\hline Total & $99.7 \pm 8.0$ & $8.3 \pm 0.7$ & $64.4 \pm 4.1$ & $46.6 \pm 3.3$ & $3.9 \pm 0.2$ & $31.3 \pm 2.6$ \\
\hline
\end{tabular}

TABLE 9: Nutrient-use efficiency of different nutrients in different growth forms in undisturbed and disturbed stands of moist tropical forest in Sunsari district, eastern Nepal.

\begin{tabular}{|c|c|c|c|c|c|c|}
\hline \multirow{2}{*}{ Components } & \multicolumn{3}{|c|}{ Undisturbed forest } & \multicolumn{3}{|c|}{ Disturbed forest } \\
\hline & $\mathrm{N}$ & $\mathrm{P}$ & $\mathrm{K}$ & $\mathrm{N}$ & $\mathrm{P}$ & K \\
\hline Herbs & 87 & 810 & 89 & 87 & 813 & 89 \\
\hline Shrubs & 122 & 1527 & 110 & 127 & 1875 & 107 \\
\hline Trees & 136 & 1417 & 169 & 138 & 1465 & 170 \\
\hline
\end{tabular}

TABLE 10: Turnover time (year) for different nutrients in standing vegetation of undisturbed and disturbed stands of moist tropical forest in Sunsari district, eastern Nepal.

\begin{tabular}{|c|c|c|c|c|c|c|}
\hline \multirow{2}{*}{ Components } & \multicolumn{3}{|c|}{ Undisturbed forest } & \multicolumn{3}{|c|}{ Disturbed forest } \\
\hline & $\mathrm{N}$ & $\mathrm{P}$ & $\mathrm{K}$ & $\mathrm{N}$ & $\mathrm{P}$ & $\mathrm{K}$ \\
\hline Herbs & 0.8 & 0.8 & 0.8 & 0.9 & 1.0 & 1.2 \\
\hline Shrubs & 9.4 & 9.3 & 8.3 & 9.4 & 9.2 & 8.4 \\
\hline Trees & 26.9 & 22.7 & 33.8 & 24.3 & 20.7 & 30.4 \\
\hline Total vegetation & 20.3 & 17.9 & 24.0 & 17.2 & 15.3 & 19.9 \\
\hline
\end{tabular}


TABLE 11: Standing state of nutrients $\left(\mathrm{kg} \mathrm{ha}^{-1}\right)$ (mean $\left.\pm \mathrm{SE}\right)$ in litter layer in undisturbed and disturbed stands of moist tropical forest in Sunsari district, eastern Nepal.

\begin{tabular}{|c|c|c|c|c|c|c|}
\hline \multirow{2}{*}{ Components } & \multicolumn{3}{|c|}{ Undisturbed forest } & \multicolumn{3}{|c|}{ Disturbed forest } \\
\hline & $\mathrm{N}$ & $\mathrm{P}$ & $\mathrm{K}$ & $\mathrm{N}$ & $\mathrm{P}$ & $\mathrm{K}$ \\
\hline Total litter mass & $55.4 \pm 4.3$ & $4.6 \pm 0.3$ & $34.3 \pm 2.8$ & $29.9 \pm 1.5$ & $2.5 \pm 0.1$ & $18.9 \pm 1.1$ \\
\hline Fresh leaf litter (\%) & 45 & 47 & 54 & 46 & 48 & 55 \\
\hline Partly decayed leaf litter (\%) & 23 & 24 & 28 & 26 & 27 & 30 \\
\hline Fresh non-leaf litter (\%) & 20 & 17 & 11 & 18 & 15 & 9 \\
\hline Partly decayed non-leaf litter (\%) & 12 & 11 & 7 & 11 & 9 & 6 \\
\hline
\end{tabular}

TABLE 12: Turnover rate $(k)$ and turnover time $(t)$ of litter nutrients on forest floor in undisturbed and disturbed stands of moist tropical forest in Sunsari district, eastern Nepal.

\begin{tabular}{lccccc}
\hline \multirow{2}{*}{ Turnover rate and time } & \multicolumn{3}{c}{ Undisturbed forest } & \multicolumn{3}{c}{ Disturbed forest } \\
& $\mathrm{N}$ & $\mathrm{P}$ & $\mathrm{K}$ & $\mathrm{N}$ & 0.67 \\
\hline Rate (per yr) & 0.69 & 0.68 & 0.66 & 0.67 & 0.64 \\
Time (yr) & 1.45 & 1.47 & 1.53 & 1.49 & 1.51 \\
\hline
\end{tabular}

TABLE 13: Nitrogen, phosphorus, and potassium budget for vegetation in undisturbed forest stand (UF) and disturbed forest stand (DF) of moist tropical forest in Sunsari district, eastern Nepal.

\begin{tabular}{|c|c|c|c|c|c|c|}
\hline \multirow{2}{*}{ Components } & \multicolumn{2}{|c|}{ Nitrogen budget } & \multicolumn{2}{|c|}{ Phosphorus budget } & \multicolumn{2}{|c|}{ Potassium budget } \\
\hline & UF & $\mathrm{DF}$ & UF & DF & UF & $\mathrm{DF}$ \\
\hline Nutrient stocks $^{1}$ & 5738.2 & 2704.4 & 537.7 & 252.9 & 5232.1 & 2470.8 \\
\hline Gross uptake ${ }^{2}$ & 282.4 & 156.8 & 30.1 & 16.5 & 217.7 & 124.2 \\
\hline Re-translocation ${ }^{2}$ & 74.7 & 40.0 & 10.7 & 5.8 & 53.5 & 23.7 \\
\hline Net uptake ${ }^{2}$ & 207.7 & 116.8 & 19.4 & 10.7 & 164.2 & 100.5 \\
\hline Return, litterfall ${ }^{2}$ & 99.7 & 46.6 & 8.3 & 3.9 & 64.4 & 31.3 \\
\hline Return, fine $\operatorname{root}^{2}$ & 43.3 & 24.0 & 3.4 & 1.9 & 36.7 & 20.2 \\
\hline Total return ${ }^{2}$ & 143.0 & 70.6 & 11.7 & 5.8 & 101.1 & 51.5 \\
\hline$\%$ total return of net uptake & 69 & 60 & 60 & 54 & 62 & 51 \\
\hline Retention in vegetation $^{2}$ & 64.7 & 46.2 & 7.7 & 4.9 & 63.1 & 49.0 \\
\hline$\%$ retention of net uptake & 31 & 40 & 40 & 46 & 38 & 49 \\
\hline Re-translocation:Gross uptake ratio & 0.26 & 0.26 & 0.36 & 0.35 & 0.25 & 0.19 \\
\hline
\end{tabular}

1. $\mathrm{Kg} \mathrm{ha}^{-1} ; 2 . \mathrm{Kg} \mathrm{ha}^{-1} \mathrm{yr}^{-1}$.

for germination, growth, and development. Relatively dense tree-vegetation with closed canopy and greater accumulation of litter prevents the leaching of nutrients from the soil thereby increasing the nutrient activities. The higher nutrients level in the soil of UF also favoured the luxuriant growth of large-sized trees resulting in higher nutrients stocks.

4.1. Nutrient Concentrations, Stocks, and Turnover. Nutrient concentrations in the plants varied in different growth forms and components. The ranges of nutrient concentrations in different growth forms were in the following order: herb $>$ shrub $>$ tree. The same order of concentrations in such growth forms was also reported in dry tropical forest of India [20]. Amongst components, the leaves contained maximum concentrations of nutrients in all growth forms. The elevated nutrient concentration makes this component an important reserve of nutrients, although it represents only a small percentage of the whole tree biomass. The concentration of $\mathrm{K}$ was relatively higher in herbs and shrubs as compared to trees. Earlier study also suggested that grasses and herbs are often high in $\mathrm{K}$ compared to woody species [21].

In the present study the foliar $\mathrm{N}$ : $\mathrm{P}$ ratio showed a decreasing trend in the order of shrubs $>$ trees $>$ herbs. The higher foliar N: P ratio in shrubs and trees may be due to high potential growth and photosynthetic rates, which allow them to use the available phosphorus relatively in greater demand. Herbs were rich in nitrogen and plant with high nitrogen status causes up to a 10 -fold increase in root absorption capacity for phosphate and vice versa [22]. It could also be the possible cause for the lower N: $\mathrm{P}$ ratio in herbs than trees and shrubs.

Nutrient stocks in the vegetation are mainly explained by the amount of biomass of the vegetation. Due to forest disturbance, the total biomass is reduced by $53 \%$ in DF in comparison to UF [19]. Consequently, the nutrient stocks of $\mathrm{N}, \mathrm{P}$, and $\mathrm{K}$ in total vegetation were more than double in UF than in the DF. The same pattern was observed in the nutrient stocks for fine root fraction which was higher in UF 


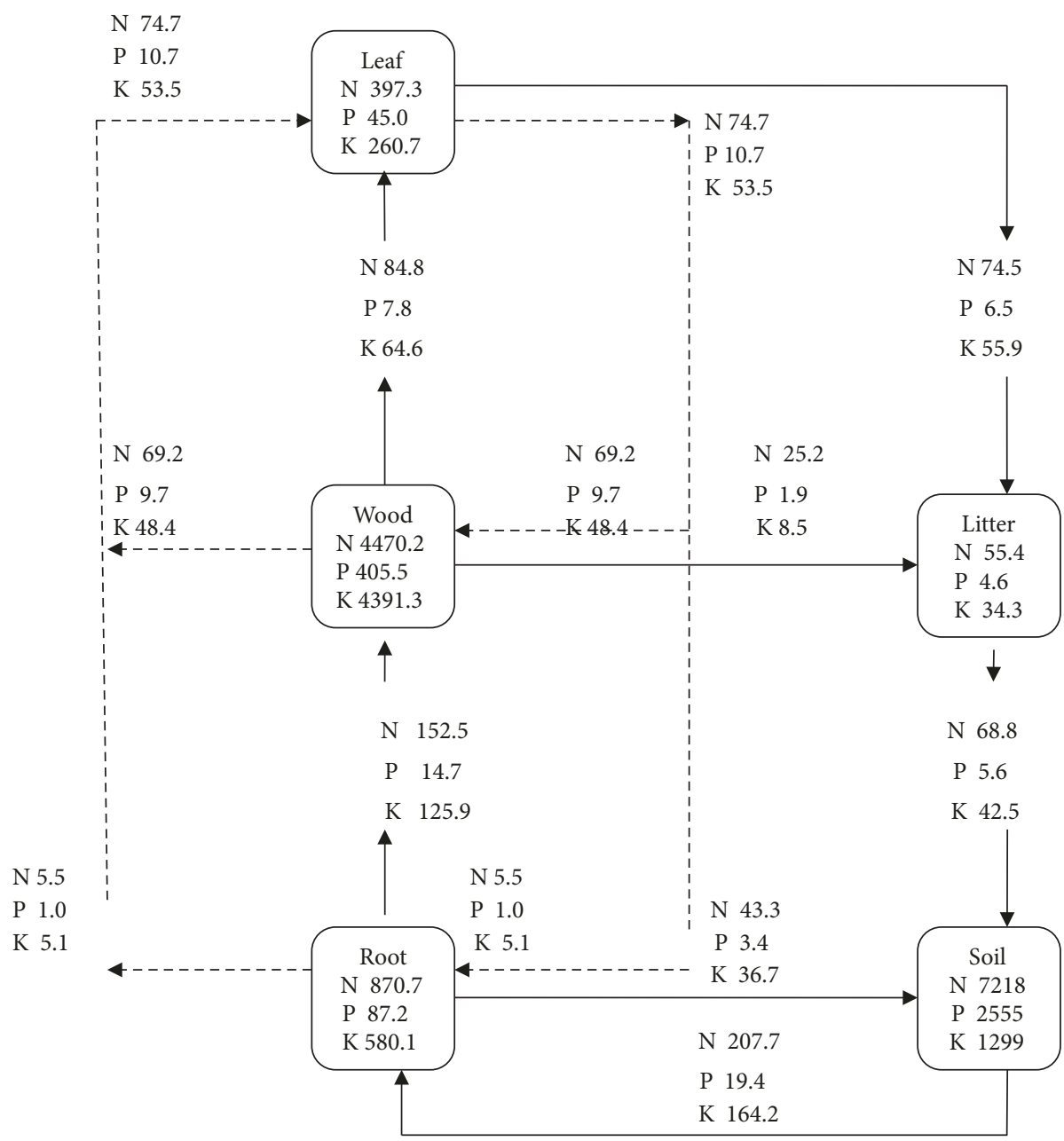

Figure 3: Model showing the distribution and cycling of nutrients, N, P, and K in undisturbed forest stand of moist tropical forest of Sunsari district eastern Nepal. Values inside compartments represent nutrient stocks $\left(\mathrm{kg} \mathrm{ha}^{-1}\right)$. Internal recycling is represented by the broken lines. Net annual fluxes between compartments are represented as arrows $\left(\mathrm{kg} \mathrm{ha}^{-1} \mathrm{yr}^{-1}\right)$. The root compartment includes coarse as well as fine roots. The wood compartment also includes aboveground nonleaf part of herbs (especially of the perennial forbs).

than DF because of higher value of fine root biomass [19]. The higher $\mathrm{N}$ stock in the fine root of $<2 \mathrm{~mm}$ diameter class reported in this study was comparable with the value reported for North American forest species [23]. However, in case of shrubs only, the case was reverse. At the DF due to reduction in canopy cover (30 to $40 \%$ ), shrub biomass increased by $28 \%$. The nutrient stocks also were greater by 1.3 times in shrub component of DF in comparison to UF. The nutrient stocks of the present forest are compared with nutrient stocks of other tropical forests (Table 14).

Knowledge of the turnover rate of nutrients is a prerequisite for understanding the availability and cycling of nutrients. This understanding is essential in describing ecosystem dynamics and in calculating plant nutrient needs. Turnover rate for nutrients in herbs was almost same in both stands of present forest. Turnover rate of nutrients in both shrubs and trees was higher for all nutrients in DF than UF indicating a faster nutrient cycling. Nutrient exchange rate is expected to be rapid during the early phase of forest recovery than mature stage [24].
4.2. Nutrient Retranslocation and Nutrient-Use Efficiency. Conspicuous internal cycling of nutrients was manifested by strong retranslocation from senescing leaves as is evident from the higher retranslocation: gross uptake ratio in present forest (Table 13). The retranslocation of nutrients is considered to be an adaptation to minimize the nutrient loss, and presumably to meet the nutrient demand of new growth [25]. Different nutrients had different recycling properties. Amongst the three nutrients studied, $\mathrm{N}$ was the most rapidly retranslocated nutrient in both stands of present forest.

Further, retranslocated amount $\left(\mathrm{kg} \mathrm{ha}^{-1} \mathrm{yr}^{-1}\right)$ of $\mathrm{N}, \mathrm{P}$, and $\mathrm{K}$ was almost double in UF in comparison to DF. The UF stand showed efficient nutrient conservation mechanism as it is at climax stage. An efficient retranslocation is a typical feature of climax forest tree species [26]. Annual retranslocation of $\mathrm{N}, \mathrm{P}$, and $\mathrm{K}$ in leaves of all growth forms ranged from 43 to $52 \%$. Up to $90 \%$ of the maximum leaf $\mathrm{N}$ and $\mathrm{P}, 70 \%$ of the $\mathrm{K}$, but none of the Ca may be translocated out of senescing leaves before abscission. Generally, plants of high nutrient status have a larger percentage $\mathrm{N}$ and $\mathrm{P}$ in soluble and 


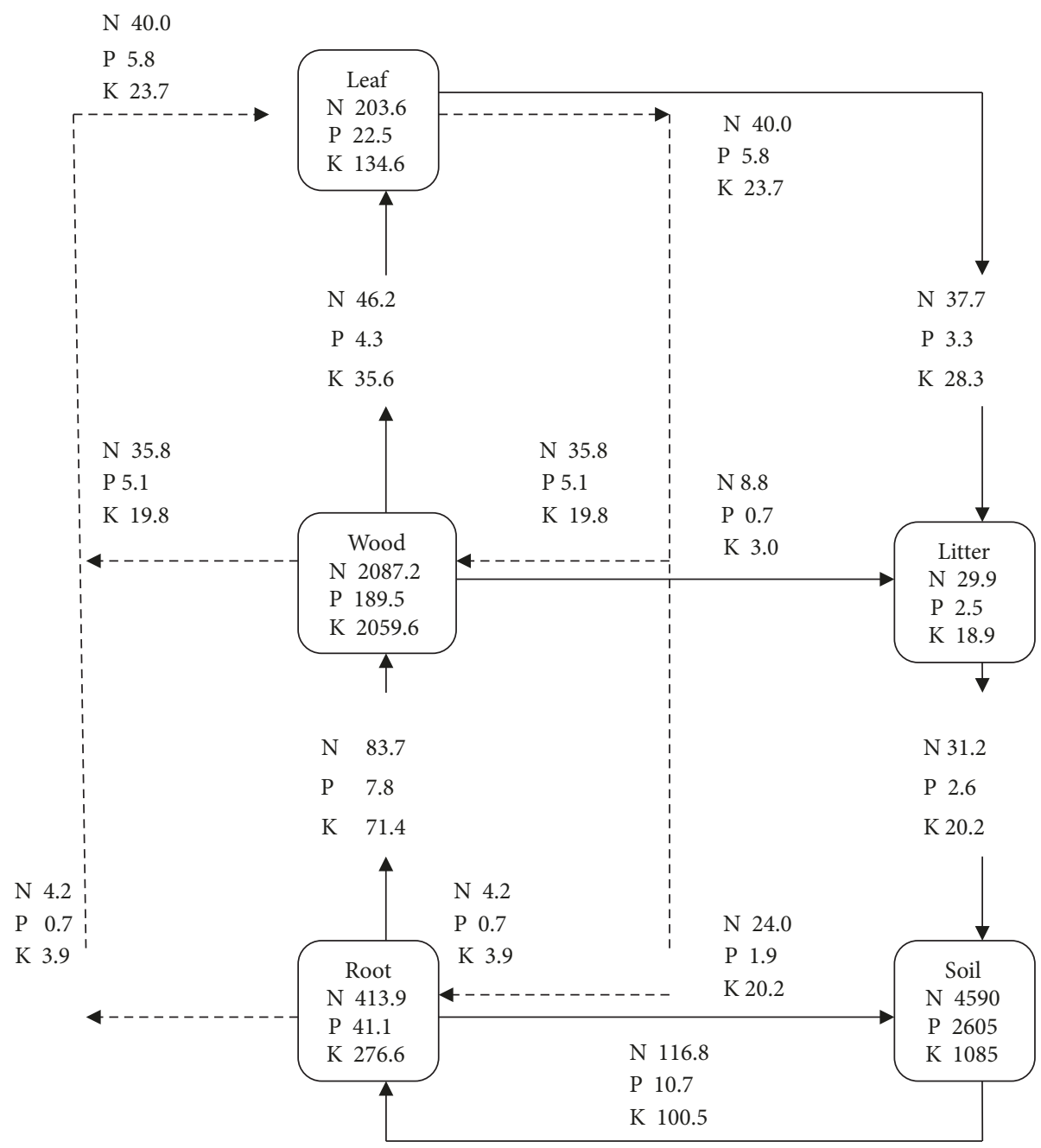

Figure 4: Model showing the distribution and cycling of nutrients, N, P, and K in disturbed forest stand of moist tropical forest of Sunsari district eastern Nepal. Values inside compartments represent nutrient stocks $\left(\mathrm{kg} \mathrm{ha}^{-1}\right)$. Internal recycling is represented by the broken lines. Net annual fluxes between compartments are represented as arrows $\left(\mathrm{kg} \mathrm{ha}^{-1} \mathrm{yr}^{-1}\right)$. The root compartment includes coarse as well as fine roots. The wood compartment also includes aboveground nonleaf part of herbs (especially of the perennial forbs).

inorganic form and retranslocate a larger proportion of their leaf $\mathrm{N}$ and $\mathrm{P}$ than plants with low nutrient status [22].

The retranslocation of larger fractions of nutrients before litterfall increased the nutrient-use efficiency in the both present forests. The $\mathrm{N}$-use efficiency of trees in the present study is high and close to the value 130 for $\mathrm{N}$, reported for efficient tropical forests [27]. The P-use efficiency of trees in both forests was within the range for tropical dry deciduous forest in India (1059) [16] and efficient tropical forests [27].

Litter fall is a major functional part of any ecosystem as it plays a vital role in regulating nutrient cycling and organic matter content. Nutrient return to the soil pool is mainly defined by litterfall, and the rest is contributed by fine roots (Table 13). Rapid turnover of litter in the forest may continually regenerate the available $\mathrm{N}, \mathrm{P}$, and $\mathrm{K}$ to support a high net production of vegetation as present in UF [19].

4.3. Nutrient Dynamics in the Context of Disturbance. The total quantity of nutrients stored in the vegetation decreased with the forest disturbance. As nutrient stock in the vegetation is explained mainly by the level of biomass, it decreased in disturbed forest having low biomass value due to cutting of trees and lopping of branches. Much reduced amount of nutrients in litter mass resulted due to rapid turnover of litter nutrients (64-69\%) on the forest floor in both forest stands. With the disturbance, the nutrient storage capacity of both vegetation and soil decreased with the exception of soil $\mathrm{P}$ which increased in DF as compared to UF.

The nutrients retranslocated during leaf senescence in UF were fairly higher than DF. It emphasizes the profound significance of internal cycling in the conservation of nutrients to support the production of new foliage in the succeeding growing season and to diminish the demand from the soil. It is assumed that nutrients retranslocated from leaves in the woody species are stored in the wood and of herbs in the belowground roots and rhizomes [15].

Of the total nutrient released to the soil, the contribution of litterfall was 1.3 to 1.9 times more than that from the fine 
TABLE 14: Comparison of nutrient storage $\left(\mathrm{kg} \mathrm{ha}^{-1}\right)$ in vegetation of some tropical forests of the world.

\begin{tabular}{|c|c|c|c|c|}
\hline \multirow{2}{*}{ Forests } & \multicolumn{3}{|c|}{ Nutrients } & \multirow{2}{*}{ References } \\
\hline & $\mathrm{N}$ & $\mathrm{P}$ & $\mathrm{K}$ & \\
\hline Moist tropical $*$ (Venezuela) & 1980 & 290 & 1820 & {$[8]$} \\
\hline \multicolumn{5}{|l|}{ Humid Sal (India) } \\
\hline Old growth $* *$ & 4454 & 403 & 2510 & [9] \\
\hline Moist tropical (Nepal) & 5738 & 538 & 5232 & Present study \\
\hline
\end{tabular}

* Nutrients in aboveground biomass. ** Nutrients reported for tree layer only.

roots. This emphasizes the importance of litterfall in nutrient cycling of moist tropical forest. The net uptake of different nutrients decreased 1.6 to 1.8 times in DF as compared to UF. Of the net uptake of different nutrients, $60-69 \%$ in UF and $51-60 \%$ in DF was returned to the soil through litter fall and fine root mortality. The nutrient budget indicated 31$49 \%$ of net uptake of different nutrients retained by vegetation over the annual cycle, retention being higher in DF than UF. Relatively higher percentage retention of nutrients in the vegetation of DF could be the nutrient conservation mechanism in nutrient poor soil of DF.

\section{Conclusions}

From the present study it can be concluded that the forest disturbance leads to the decrease in nutrient storage capacity of vegetation. Amongst the different disturbance activities, stem harvest results in maximum loss of nutrients because of higher biomass retention. Present forest is efficient with respect to nutrient-use efficiency. It is evident from higher retranslocation of nutrients (up to 74\%) before litterfall. Higher retranslocation of nutrients from senescing leaves in UF exhibits nutrient conservation mechanism and tight cycling of nutrients. Both litterfall and fine roots play the major roles for the return of nutrients to soil. Contribution of litterfall for the return of nutrients from plant to the soil is higher as compared to that through fine roots (about 1.5 times greater). The higher value of \% retention of net uptake of $\mathrm{N}$, $\mathrm{P}$, and $\mathrm{K}$ in DF suggests nutrient conservation mechanism in nutrient poor soil. To preserve the nutrient loss in disturbed tropical forest, immediate management actions should be taken by concerned authorities and forest users.

\section{Data Availability}

The data used to support the findings of this study are included within the article.

\section{Conflicts of Interest}

The authors declare that there are no any conflicts of interest regarding this article.

\section{References}

[1] P. M. Vitousek and L. R. Sanford Jr, "Nutrient cycling in moist tropical forest," Annual Review of Ecology and Systematics, vol. 17, pp. 137-167, 1986.
[2] I. C. Meier, C. Leuschner, and D. Hertel, "Nutrient return with leaf litter fall in Fagus sylvatica forests across a soil fertility gradient," Plant Ecology, vol. 177, no. 1, pp. 99-112, 2005.

[3] S. M. Gleason, J. Read, A. Ares, and D. J. Metcalfe, "Species-soil associations, disturbance, and nutrient cycling in an Australian tropical rainforest," Oecologia, vol. 162, no. 4, pp. 1047-1058, 2010.

[4] C. F. Jordan, Nutrient Cycling in Tropical Forest Ecosystems; Principles and their Application in Management and Conservation, John Wiley \& Sons, Chichester, England, 1985.

[5] L. A. Cernusak, K. Winter, J. W. Dalling et al., "Tropical forest responses to increasing atmospheric $\mathrm{CO} 2$ : Current knowledge and opportunities for future research," Functional Plant Biology, vol. 40, no. 6, pp. 531-551, 2013.

[6] S. J. Wright, J. B. Yavitt, N. Wurzburger et al., "Potassium, phosphorus, or nitrogen limit root allocation, tree growth, or litter production in a lowland tropical forest," Ecology, vol. 92, no. 8, pp. 1616-1625, 2011.

[7] P. G. Murphy and A. E. Lugo, "Ecology of tropical dry forest," Annual Review of Ecology, Evolution, and Systematics, vol. 17, pp. 67-88, 1986.

[8] H. Hase and H. Folster, "Bioelement inventory of a tropical (semi-) evergreen seasonal forest on eutrophic alluvial soils, western Llanos, Venezuela.," Acta Oecologica. Oecologia Plantarum, vol. 3, no. 4, pp. 331-346, 1982.

[9] S. P. Singh and J. S. Singh, "Ecology of Central Himalayan forests with special reference to sal forest ecosystem," in Perspectives in Ecology, J. S. Singh and B. Gopal, Eds., pp. 193-232, Jagmander Book Agency, New Delhi, 1989.

[10] J. S. Singh and S. P. Singh, Forests of Himalaya, Gyanodaya Prakashan, Nainital, India, 1992.

[11] Y. Malhi, L. E. O. C. Aragão, D. B. Metcalfe et al., "Comprehensive assessment of carbon productivity, allocation and storage in three Amazonian forests," GCB Bioenergy, vol. 15, no. 5, pp. 1255-1274, 2009.

[12] K. Peach and M. V. Tracey, Modern Methods of Plant Analysis, vol. 1, Springer-Verlag, Berlin, 1956.

[13] S. E. Allen, H. M. Grimshaw, J. A. Parkinson, and C. Quarmby, Chemical Analysis of Ecological Materials, Blackwell Scientific Publications, Oxford, 1974.

[14] M. L. Jackson, Soil Chemical Analysis, Printice Hall, Englewood Cliffs, New Jersey, 1958.

[15] S. K. Tripathi and K. P. Singh, "Productivity and nutrient cycling in recently harvested and mature bamboo savannas in the dry tropics," Journal of Applied Ecology, vol. 31, no. 1, pp. 109-124, 1994.

[16] K. P. Singh, "Mineral nutrients in tropical dry deciduous forest and savanna ecosystems in India," Mineral nutrients in tropical forest and savanna ecosystems, pp. 153-168, 1989. 
[17] P. Vitousek, "Nutrient cycling and nutrient use efficiency." The American Naturalist, vol. 119, no. 4, pp. 553-572, 1982.

[18] H. Jenny, S. P. Gessel, and F. T. Bingham, "Comparative study of decomposition rates of organic matter in temperate and tropical regions," Soil Science, vol. 68, no. 6, pp. 419-432, 1949.

[19] T. P. Gautam and T. N. Mandal, "Effect of disturbance on biomass, production and carbon dynamics in moist tropical forest of eastern Nepal," Forest Ecosystems, vol. 3, no. 11, pp. 1010, 2016.

[20] L. Singh and J. S. Singh, "Storage and flux of nutrients in a dry tropical forest in India," Annals of Botany, vol. 68, no. 3, pp. 275284, 1991.

[21] T. J. Fahey, M. O. Hill, P. A. Stevens, M. Hornung, and P. Rowland, "Nutrient accumulation in vegetation following conventional and whole-tree harvest of sitka spruce plantations in North Wales," Forestry, vol. 64, no. 3, pp. 271-288, 1991.

[22] F. S. Chapin, “The Mineral Nutrition of Wild Plants," Annual Review of Ecology, Evolution, and Systematics, vol. 11, no. 1, pp. 233-260, 1980.

[23] L. H. Comas and D. M. Eissenstat, "Patterns in root trait variation among 25 co-existing North American forest species," New Phytologist, vol. 182, no. 4, pp. 919-928, 2009.

[24] E. P. Odum, “The strategy of ecosystem development," Science, vol. 164, no. 3877, pp. 262-270, 1969.

[25] D. N. Fife and E. K. S. Nambiar, "Accumulation and retranslocation of mineral nutrients in developing needles in relation to seasonal growth of young radiata pine trees," Annals of Botany, vol. 50, no. 6, pp. 817-829, 1982.

[26] H. Staaf, "Plant nutrient changes in beech leaves during senescence as influenced by site characteristics ( Fagus sylvatica).," Acta Oecologica, Oecologia Plantarum, vol. 3, no. 2, pp. 161-170, 1982.

[27] P. M. Vitousek, "Litterfall, nutrient cycling, and nutrient limitation in tropical forests.," Ecology, vol. 65, no. 1, pp. 285-298, 1984. 

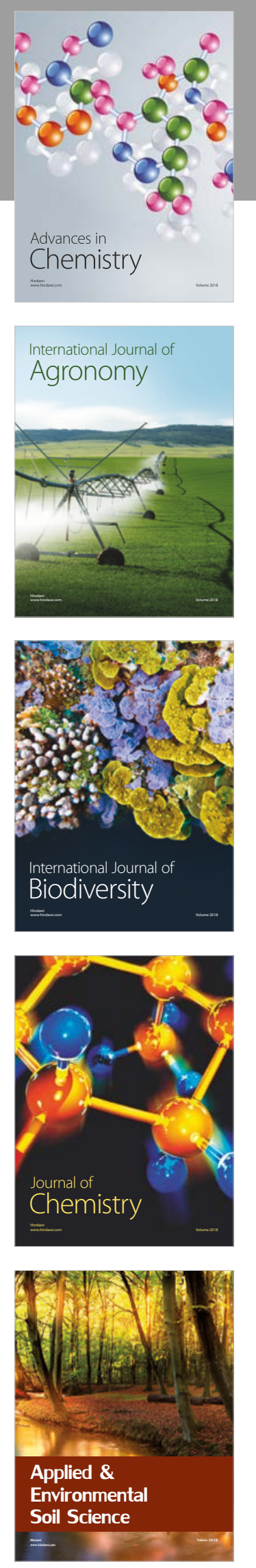

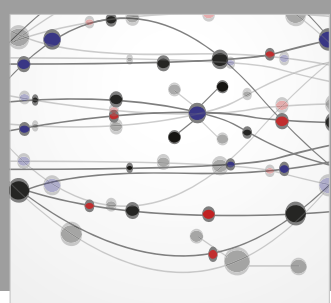

The Scientific World Journal

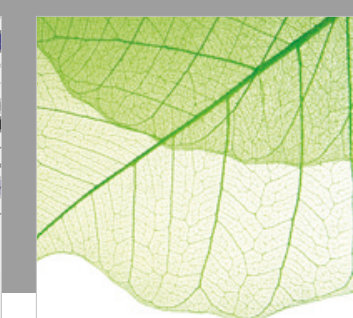

Journal of Botany

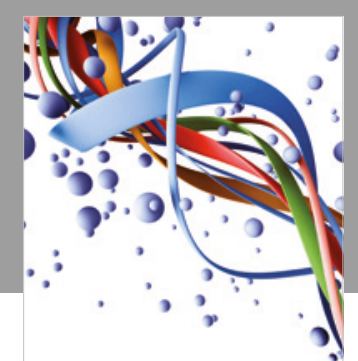

Scientifica

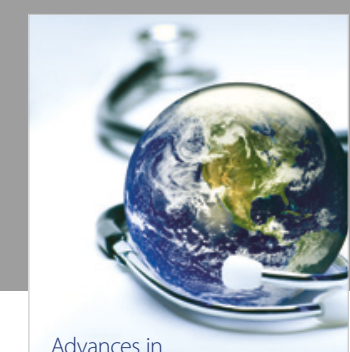

Public Health

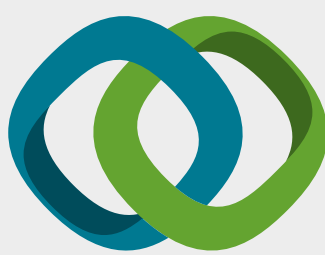

Hindawi

Submit your manuscripts at

www.hindawi.com
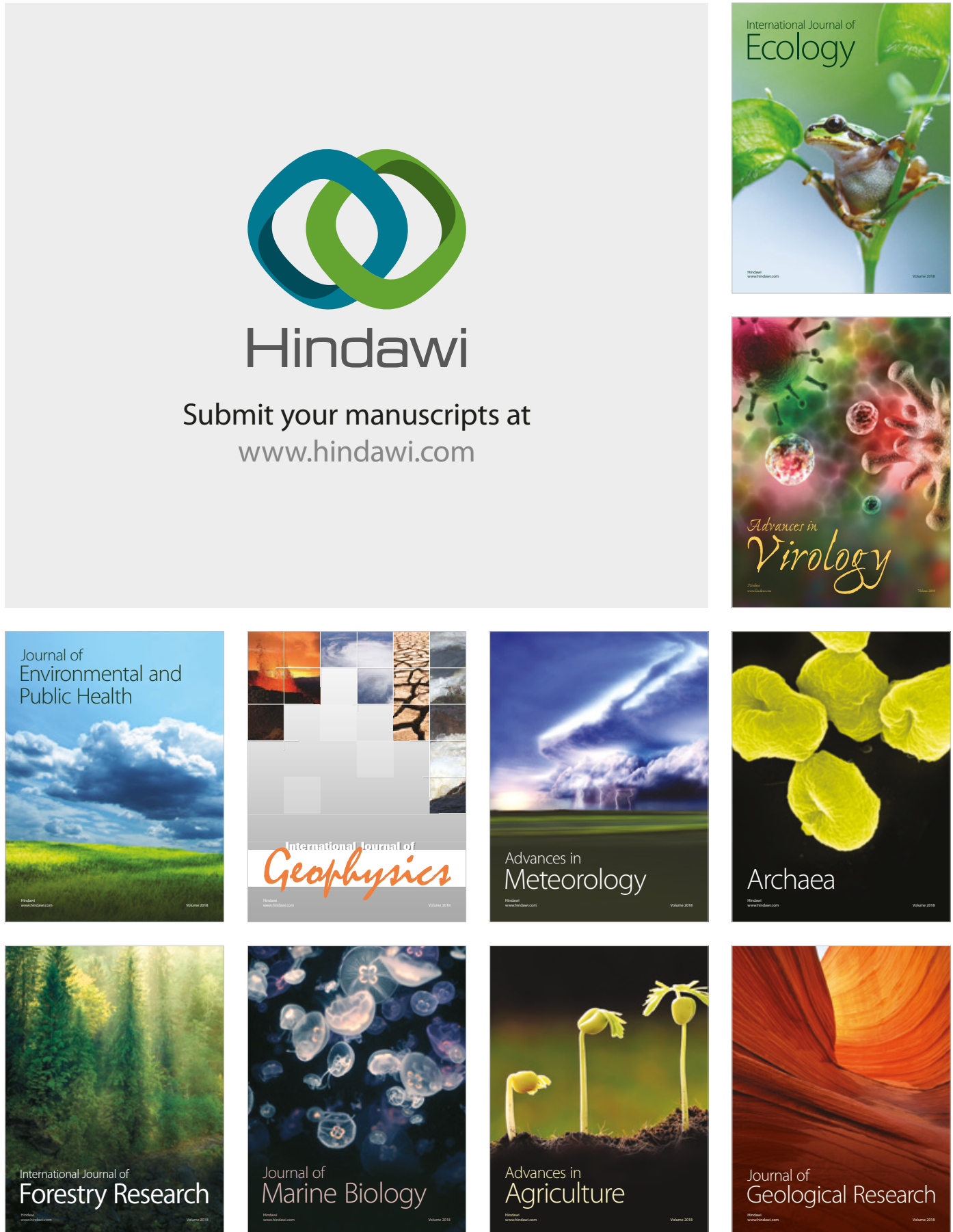

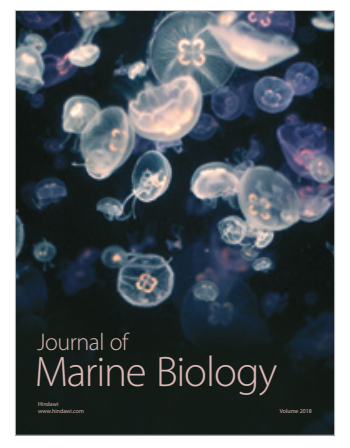

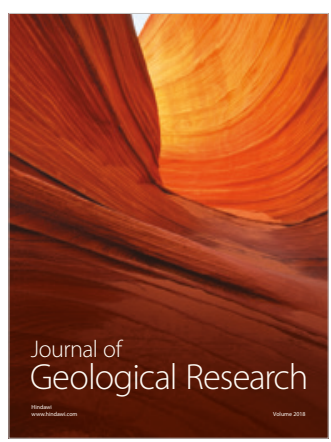

